\title{
Watercore in Apple Landraces (Malus domestica Borkh.) as a quality indicator
}

\author{
La vitrescencia en cultivares locales de manzano (Malus domestica Borkh.) \\ como indicador de calidad
}

\begin{abstract}
Alberto Arnal ${ }^{1}$

\begin{tabular}{l} 
ARTICLE DATA \\
\hline $\begin{array}{l}\text { 1. Researcher, Ph.D., IMIDRA, Madrid, Spain, a.arnal@ } \\
\text { alumnos.upm.es }\end{array}$
\end{tabular}

Cite: Arnal, A. (2021). Watercore in Apple Landraces (Malus domestica Borkh.) as a quality indicator. Revista de Ciencias Agrícolas. 38(1): 158-165. doi: https://doi.org/10.22267/rcia.213801.153

Received: August 312020.

Accepted: May 072021.

ABSTRACT

Watercore is the presence of a vitrified texture intruded in the pulp of the fruit. It is found in fruits from different genus and families; and it has been studied in apples. Watercore was described, in apples, as a texture with differential sensorial characteristics in relationship with the ordinary pulp, and its presence is currently considered a defect in apple production, causing economic losses. In this study, it is described as a dichotomous descriptor. We analysed 641 apples from a region belonging to Central Spain (Guadarrama mountain range and the close Tagus Basin River); it was found that around 30\% of those apples shown this characteristic, being practically all of them from landraces. Studies related to traditional cultivars do not analyze such characteristic, considered up today as a defect. Nevertheless, we discuss that watercore can have some potential as it gives to apple a distinct appearance and aroma, all of them of value in differential quality and international seal protection. As a result, we conclude our preliminary analysis that it is highly recommended to take into consideration watercore as a descriptor in apple characterizations.
\end{abstract}
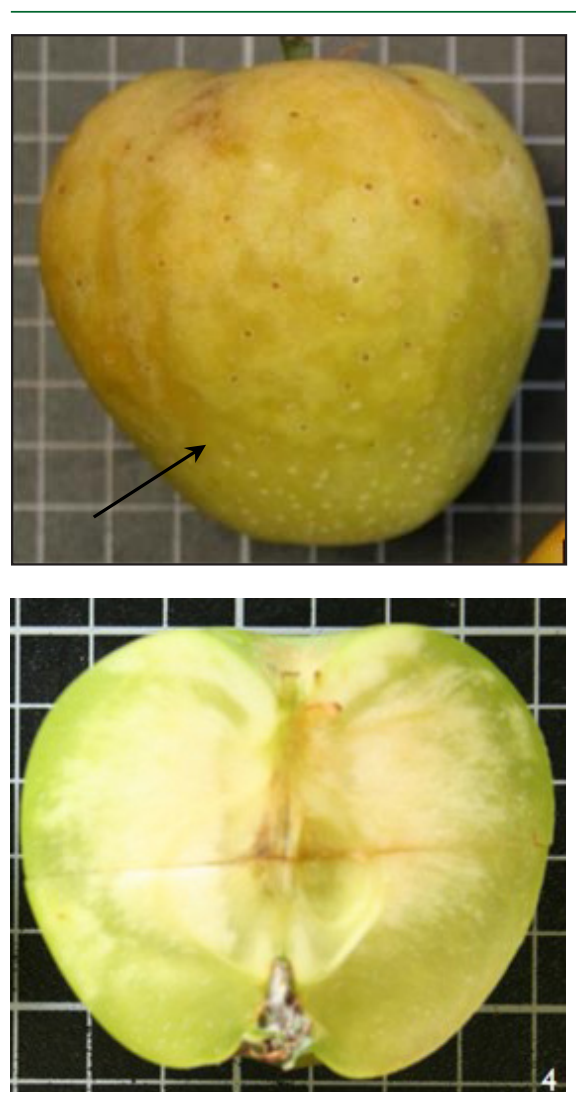

Keywords: germplasm; morphological descriptor; quality; rural development; traditional cultivars; vitreous texture.

\section{RESUMEN}

El corazón acuoso, núcleo acuoso o vitrescencia es la presencia de una textura vitrificada en la pulpa del fruto. Se encuentra en frutas de diferentes géneros y familias, y se ha estudiado en manzano. El corazón acuoso se describió, para la manzana, como una textura con características sensoriales diferenciales en relación con su pulpa ordinaria, y su presencia se considera actualmente un defecto en la producción de manzana, provocando pérdidas económicas. En este estudio, se describe el corazón acuoso como un descriptor dicotómico. Se analizaron 641 manzanas de una zona del centro de España (sierra de Guadarrama y su zona próxima en la cuenca del Tajo), encontrándose que alrededor del 30\% de esas manzanas presentaban esta característica, siendo prácticamente todas de 
cultivares tradicionales. Los estudios morfológicos de germoplasma relacionados con estos cultivares no analizan tal característica, considerada hoy como un defecto. Sin embargo, discutimos que este corazón acuoso puede tener cierto potencial, ya que le da a la manzana una apariencia y un aroma distintos, todos ellos de posible valor en términos de calidad diferenciada, con el correspondiente sello de protección internacional. Como resultado, se concluye con nuestro análisis preliminar que es muy recomendable tener en cuenta el núcleo de agua como descriptor dentro de las caracterizaciones de manzano.

Palabras clave: calidad; cultivar tradicional; desarrollo rural; descriptor morfológico; germoplasma; textura vítrea.

\section{INTRODUCTION}

Watercore, less known as vitrification, is a translucent or glassy texture in the pulp of the apple (Figure 1). According to Beaudry (2014), Paul Sorauer performed the first published description of this phenomenon in apples in 1886. He described it as a glassy flesh, which was somewhat distinctly sweeter, firmer, with less intercellular air and starch, smelling differently, but also differenced for browning quicker than the unaffected tissue (Beaudry, 2014). Although watercore has been studied in apples, this characteristic has also been identified in peach [Prunus persica (L.) Stokes] (Yamane et al., 2020), pear (Pyrus spp.) (Liu et al., 2021) and mangosteen (Garcinia mangostana L.) (Matra et al., 2019).

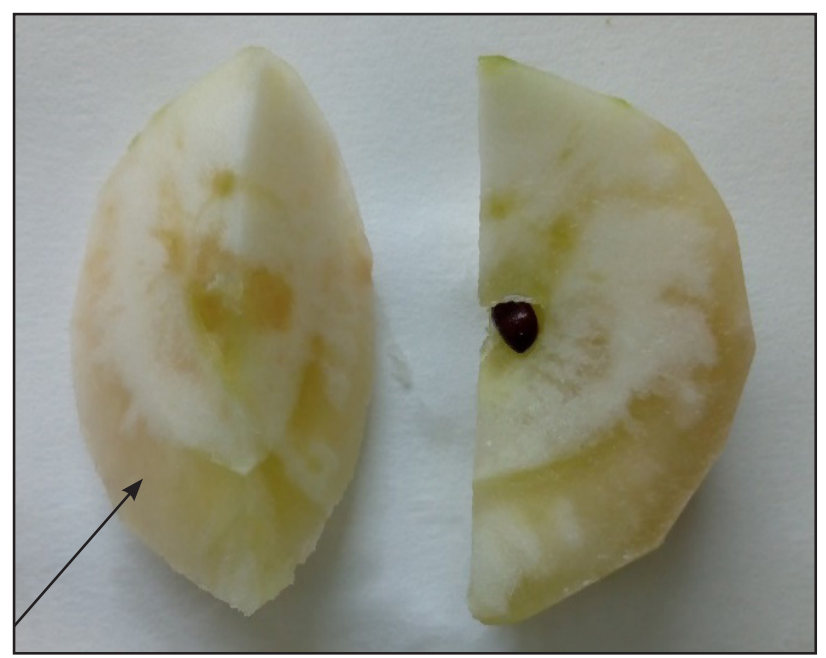

Figure 1. Watercore in a madrilean landrace apple (black arrow) in a freshly cut apple.
The vitreous appearance is due to an invasion of a liquid rich in sorbitol. Sorbitol is polyhydric sugar alcohol synthetized from glucose by hydrogenation. This liquid fills the intercellular spaces, which are normally occupied by air (Beaudry, 2014; Liu et al., 2021). Vitrification is currently considered a defect in fruit crops, alleging that a deficiency of calcium in the soil might be the main cause (Calvo and Candan, 2013), being problems in storage one of the most negative consequences (Saquet, 2020). Nevertheless, susceptibility to watercore also depends on the cultivar, cultural practices, disorders in the water regime, contrasts in temperature, high radiation, and an unbalanced ratio source to sink ratio (Beaudry, 2014). As apples are one of the major temperate crops (Pereira-Lorenzo et al., 2018), there exist many techniques to detect watercore such as light transmission, infrared spectroscopy, thermography, nuclear magnetic resonance, $\mathrm{X}$-ray computed tomography, and even fruit density (Beaudry, 2014; Huang et al., 2020).

Although this defect is important in crops and depends on the cultivar, international authorities such as the International Union for the Protection of Plant Varieties (UPOV, 2018) does not include this characteristic in their manual. In addition, research published on apple landraces is not considering watercore, although the great effort done on phenotyping. Some examples of those works are the one from India (Dolker et al., 2021) and from Greece (Ganopoulos et al., 2018). 
Among other purposes, research in traditional cultivars is oriented towards the characteristics' detection of agronomic interest, sensory evaluation, and ultimately, their possible commercialization as in the case of the 'Pero de Ceheguín' (Martínez et al., 2020). There is a European legal framework favourable to the use of local agricultural resources through the Rural Development (UE Regulation $n \quad{ }^{\circ} 1305 / 2013$ ) and labelling on quality regimes (UE Regulation $\left.n{ }^{\circ} 1151 / 2012\right)$. The legal framework is manifested in the product with a seal that guarantees superior characteristics compared to a general set of products of the same type. As a result, there is the Protected Designation of Origin (PDO) 'Reineta del Bierzo' and the Protected Geographical Indication (PGI) 'Poma de Girona'. These two products added in 2017 an economic value in the destination market of more than three and a half million euros (MAPA, 2020). Furthermore, 'Esperiega de Ademuz', 'Pero de Ceheguín', and 'Pero de La Hiruela' are also some apple cultivars with certain rename in Spain (specially the first one), but they are not enjoying any international seal yet.

The aim of this research is to analyse the presence and extent of watercore in traditional cultivars from the region of Madrid (Spain) to consider this characteristic in both, germplasm characterisation, and in sensorial analysis.

\section{MATERIAL AND METHODS}

A set of 463 apples from 51 trees belonging to 20 apple landraces from rural regions of Madrid Spain (Table 1) were evaluated with 178 apples from 6 references (Table 2) for the 'watercore' trait. Apple trees belong to several rural areas that belong to the region of Madrid (Guadarrama mountain range and the Tagus Basin River). The Guadarrama area is $1.200 \mathrm{~m}$ a.s.l. on average, although it can reach $2.000 \mathrm{~m}$ a.s.l., with a temperate climate that still retains some Mediterranean traits from the surrounding such as hot summers and summer drought.

Table 1. Number of apples sampled by landrace.

\begin{tabular}{lc}
\hline Landrace & Apples \\
\hline Agridulce & 10 \\
Amarillo de el Paular & 24 \\
Camueso & 35 \\
Camueso tardío & 8 \\
Camueso temprano & 10 \\
De Chapa & 30 \\
De Rosa & 15 \\
Del Ortel & 10 \\
Esperiega & 11 \\
Hojancas & 33 \\
Pepita de melón & 62 \\
Pero de Aragón & 38 \\
\hline
\end{tabular}

\begin{tabular}{lc}
\hline Landrace & Apples \\
\hline Pero gordo & 15 \\
Pero pardo & 37 \\
Pero real & 28 \\
Rabudas & 0 \\
Reineta & 35 \\
Rojillo & 9 \\
Rojillo temprano & 4 \\
Rojo & 34 \\
San Felipe & 0 \\
Temprano & 5 \\
Verde Doncella & 10 \\
Total & $\mathbf{4 6 3}$ \\
\hline
\end{tabular}


Besides, their soils are composed of granites, slates, and schists, which gives rather an acidic $\mathrm{pH}$. On the other hand, the Tagus area is around 450-700 $\mathrm{m}$ a.s.l., with a typical Mediterranean climate. Soils on this area are quaternary alluvial terraces with detritic materials, margous and calcareous, with a basic $\mathrm{pH}$.

Table 2. Number of apples sampled by reference.

\begin{tabular}{lc}
\hline Reference & Apples \\
\hline Fuji & 30 \\
Gala & 48 \\
Golden & 30 \\
Granny Smith & 20 \\
Reineta Blanca & 25 \\
Verde Doncella & 25 \\
Total & $\mathbf{1 7 8}$ \\
\hline
\end{tabular}

The cultivars are conserved in a regional collection. As this germplasm bank is located in the area of the Tagus basin, the soil of the experimental station is a calcareous Fluvisol with a pH around 8.5 and a calcium concentration around $23 \mathrm{mEq} / 100 \mathrm{~g}$ in the first $90 \mathrm{~cm}$. As the climate from the collection is Mediterranean, trees were irrigated from May to September every two weeks due to the existence of droughts during the summer. Apples were collected when ripening, during September-October 2016 to 2019 and preserved at around $4-7^{\circ} \mathrm{C}$ until characterisation, which was performed in the following days or weeks. Apple ripening was considered achieved after skin colour turns into red, yellow or light green, depending on the cultivar.

As we did not find any similar method for this trait in bibliography, in this research, we considered watercore as a dichotomous character (absence/presence) with a binary output ( 0 and 1 , respectively); it was evaluated by visual inspection through two cuts in each apple, one parallel to its pedicel and other perpendicular to the first cut. Apples were evaluated during the following days after harvested to prevent apples from spoiling.

In this descriptive analysis, the central value considered for the chi-squared test $\left(\chi^{2}\right)$ was the mode, and the significance level $(\alpha)$ was set at 0.05 . This statistical analysis was run with JMP 9 software (SAS, 2019), and graphic outputs were processed with Inkscape (Inkscape Project, 2020).

\section{RESULTS AND DISCUSSION}

A vitreous texture was observed in 137 apples (21\% out of 641 samples, Figure 2). Nevertheless, this percentage raised to $29 \%$ considering only traditional landraces, as no references shown this character. Only one 'Verde Doncella' from references shown watercore. Although this cultivar is considered as a reference in this study, 'Verde Doncella' is a Spanish traditional cultivar (Arnal et al., 2020). In consequence, there existed significant differences between both type of cultivars, as $\chi^{2}$ was $92.155(\mathrm{P}<0.0001$; Figure 2). 


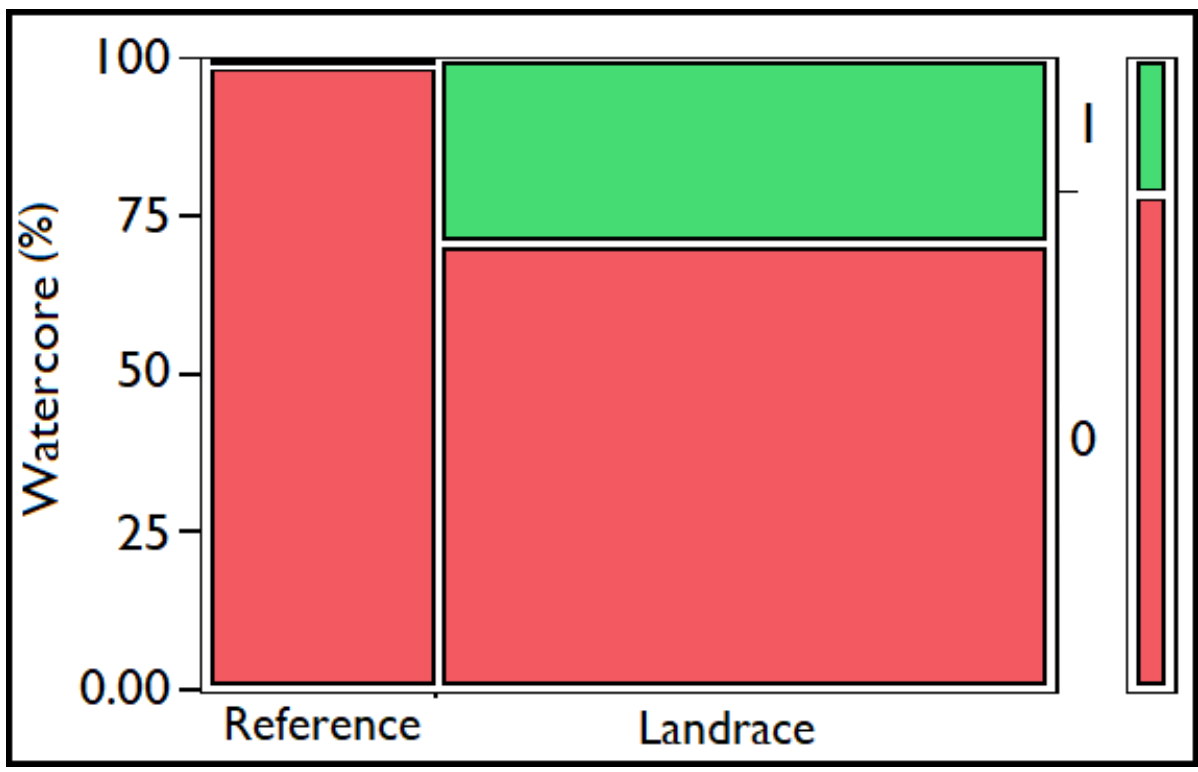

Figure 2. Contingency table between types of cultivar. 0 , Red, no watercore; 1 , green, watercore presence. The larger the green square, the more watercore counted.

This vitreous texture was seen in all parts of the pulp of the fruit as we noted vitreous texture intrusions around the inner core (including the loculi), in the middle of the pulp following the nerves, and below the peel of the apple (Figure 3) independently of the cultivar. Our results are in agreement with Beaudry (2014) who reported that this texture can be radial and gathered in vascular strands. We also detected free liquid accumulations surrounding the seeds in apples with severe watercore.

The presence of watercore in the pulp of traditional apples is noticed in works compiling traditional knowledge under the name of ice apples or frozen apples, such as 'Ciri' or 'Cirio', 'Cor glaçat' (Centre de Conservació de Plantes Cultivades, 2020), 'Gelata' and 'Gelato Cola' in Italy (Marconi et al., 2018; Slow Food Foundation, 2019). Thus, it seems a trait circumscribed to the distribution of the traditional apple tree crop.
As noted before, a deficiency of calcium in the soil is linked to vitrescence. In this study, there were no differences in soil condition, including $\mathrm{pH}$, cultural practices, radiation, temperatureandirrigation between landraces, and traditional individuals, as all of them were managed under the same conditions and planted in the same experimental station. Related to soils, the $\mathrm{pH}$ of the experimental station was around 8.5 with no calcium limitation. Consequently, the differences found might be linked to cultivar and/or variations in physiology due to the relationship between leaf area surface and fruit production, as the references are supposedly susceptible to Watercore (Beaudry, 2014). Nevertheless, the effect of temperature could explain in some extent the vitrification detected, since Calvo and Candan (2013) indicate that one type of watercore can appear under unusual and very hot conditions like the ones existing in the Mediterranean summer. 


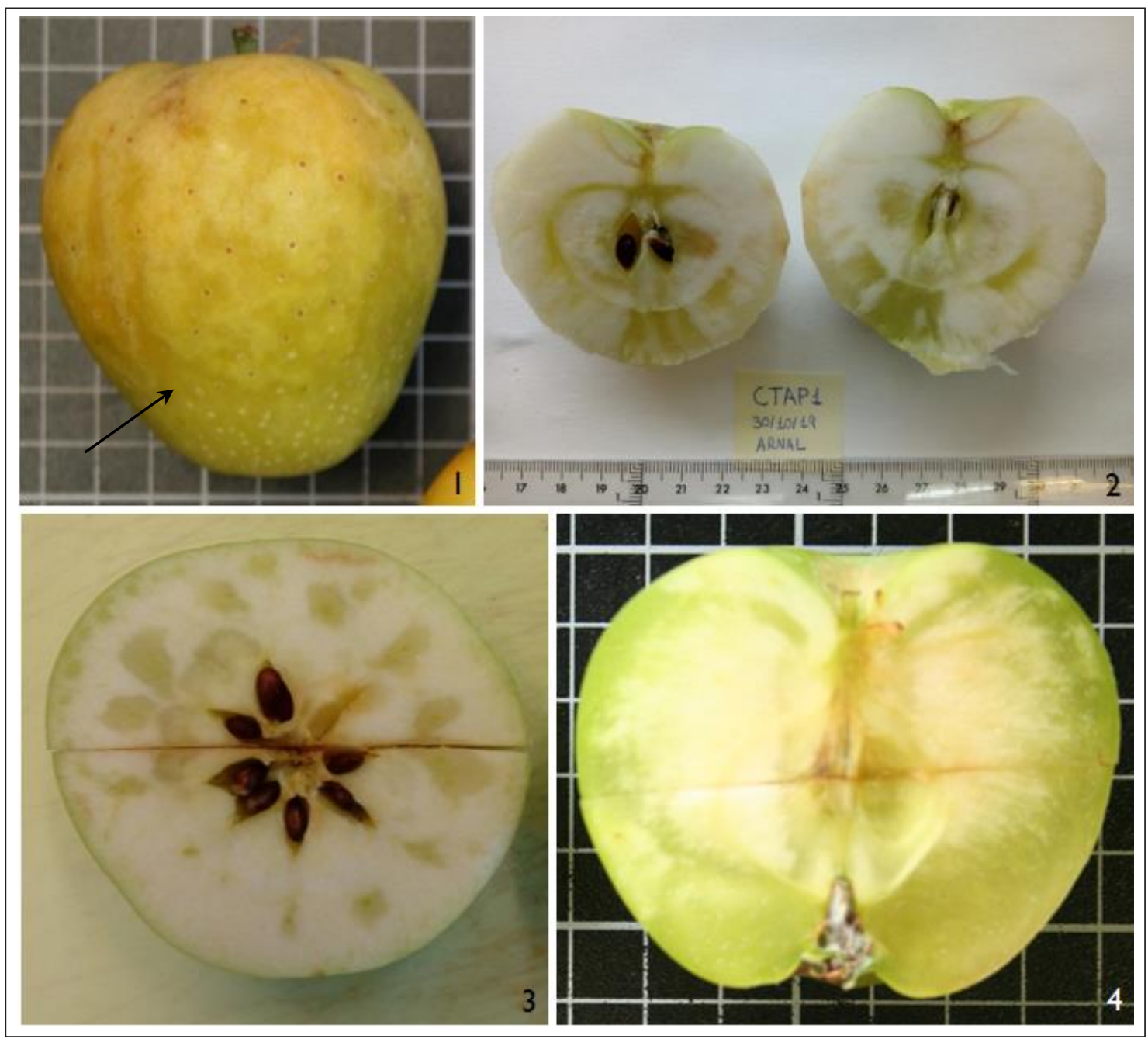

Figure 3. Watercore detected in traditional apples. 1, from the outside; 2 and 4, from a cut along pedicel, and 3, from a cut across the loculi.

So far, watercore has not been included in morphological characterizations despite its effect on marketability and sensory qualities, as noted early by Beaudry (2014) and recently by Tanaka et al. (2020), who found that watercored apples were more valuated than ordinary apples in a sensorial analysis. Russetting is an example of a defect that highly devaluates fruit quality of modern glossy apples, but it may be interesting in traditional cultivars due to its visual appearance and link to flavour (Orange Pippin Ltd., 2020).
As a result, watercore information should be considered in germplasm evaluations to detect cultivar potential. Following to Beaudry (2014) and Liu et al. (2021), vitrescence gives to the apple a marble appearance, a crunchy texture, a delicate aroma, and an intense sweetness, which might be interesting in terms of differentiated quality. The efforts to promote local products adapted to regional environmental conditions also impulse rural development within the European Rural Developmentand theSustainable Development Goals (SDGs) of the 2030 Agenda. 


\section{CONCLUSIONS}

Watercore is a common characteristic shared in traditional apple cultivars from rural regions of Madrid (Spain). Due to its impact on agronomy and fruit quality, it is highly recommended to consider this descriptor in the accession documentation of apple germplasm characterization and in sensorial descriptions.

\section{ACKNOWLEDGEMENTS}

This study was supported by the research project FP16-ETNOB "Prospection, characterization, ethnobotanical documentation and conservation of traditional horticultural varieties of the region of Madrid" funded by the local government of Madrid (Spain). A. Arnal thanks INIA (National Institute for Agricultural and Food Research and Technology), for the pre-doctoral agrifood contract in state Centers of Agricultural and Food Research (FPI-INIA 2015). The author also thanks to his PhD supervisors (Almudena Lázaro and Javier Tardío) for their support in collecting the apples during 2019.

Conflict of interests: The author declare that there is no conflict of interest.

\section{BIBLIOGRAPHIC REFERENCES}

Arnal, A.; Gogorcena, Y.; Tardío, J. (2020). Simple Sequence Repeat Characterisation of Traditional Apple Cultivars (Malus domestica Borkh.) Grown in the Region of Madrid (Central Spain) Plant Molecular Biology Reporter. 38(4): 676-690. doi: https://doi.org/10.1007/s11105-020-01240-z

Beaudry, R. (2014). Watercore in Apples: Causes, concerns, detection and sorting. Postharvest Laboratory. Michigan State University. 12p. Retrieved from https://www.canr.msu.edu/ uploads/files/Watercore_in_apples.pdf
Calvo, G.; Candan, A.P. (2013). Guía para la identificación de fisiopatías en manzanas y peras. Second edition. Río Negro: INTA Ediciones. Serie Divulgación. 19p.

Centre de Conservació de Plantes Cultivades. (2020). Fruiterar de salvaguarda de varietats locals. Olot: Parc Natural de la Zona Volcànica de la Garrotxa. 4p.

Dolker, T.; Kumar, D.; Chandel, J.S.; Angmo, S. Chaurasia, 0. P.; Stobdan, T. (2021). Phenological and Pomological Characteristics of Native Apple (Malus domestica Borkh.) Cultivars of Trans-Himalayan Ladakh, India. Defence Life Science Journal. 6(1): 64-69. doi: https://doi. org/10.14429/dlsj.6.15726

Ganopoulos, I.; Tourvas, N.; Xanthopoulou, A.; Aravanopoulos, F. A.; Avramidou, E.; Zambounis, A.; Tsaftaris, A.; Madesis, P.; Sotiropoulos, T.; Koutinas, N. (2018). Phenotypic and molecular characterization of apple (Malus $x$ domestica Borkh) genetic resources in Greece. Scientia Agricola. 75(6): 509-518. doi: https://doi. org/10.1590/1678-992X-2016-0499

Huang, Y.; Lu, R.; Cheng, K. (2020). Detection of internal defect of apples by a multichannel Vis/ NIRspectroscopic system. Postharvest Biology and Technology. 161: 111065. doi: https://doi. org/10.1016/j.postharvbio.2019.111065

Inkscape Project. (2020). Inkscape. Retrieved from https://inkscape.org

Liu, X. ; Fan, H. M.; Liu, D. H.; Liu, J.; Shen, Y.; Zhang, J.; Wei, J.; Wang, C.L. (2021). Transcriptome and Metabolome Analyses Provide Insights into the Watercore Disorder on "Akibae" Pear Fruit. International Journal of Molecular Sciences. 22(9): 4911. doi: https://doi.org/10.3390/ ijms22094911

MAPA-Ministerio de Agricultura, Pesca y Alimentación. (2020). Datos de las Denominaciones de Origen Protegidas (D.O.P.), Indicaciones Geográficas Protegidas (I.G.P.) y Especialidades Tradicionales Garantizadas (E.T.G.) de Productos Agroalimentarios. 2019 , 3rd edition. Madrid: Ministerio de Agricultura, Pesca y Alimentación. 129p. 
Marconi, G.; Ferradini, N.; Russi, L.; Concezzi, L.; Veronesi, F.; Albertini, E. (2018). Genetic characterization of the apple germplasm collection in central Italy: the value of local varieties. Frontiers in Plant Science. 9: 1460. doi: https://doi.org/10.3389/fpls.2018.01460

Martínez, R., Legua, P.; Hernández, F.; CarbonellBarrachina, A.A.; Gogorcena, Y.; MartínezNicolás, J.J.; Melgarejo, P. (2020). Molecular, Physico-Chemical and Sensory Characterization of the Traditional Spanish Apple Variety 'Pero de Cehegín. Agronomy-Basel. 10(8): 1-19. doi: https://doi.org/10.3390/agronomy10081093

Matra, D. D.; Kozaki, T.; Ishii, K.; Poerwanto, R.; Inoue, E. (2019) Comparative transcriptome analysis of translucent flesh disorder in mangosteen (Garcinia mangostana L.) fruits in response to different water regimes. PLOS ONE. 14(7): e0219976. doi: https://doi.org/10.1371/journal. pone.0219976

Orange Pippin Ltd. (2020). The Flavor of Russet Apples. Retrieved from https://www. orangepippintrees.com/articles/gardening/ flavor-of-russet-apples

Pereira-Lorenzo, S.; Fischer, M.; Ramos-Cabrer, A. M.; Castro, I. (2018). Apple (Malus spp.) Breeding: Present and Future. In: Al-Khayri, J.; Jain, S.M.; Johnson, D.V. Advances in Plant Breeding Strategies: Fruits. Volume 3. pp. 3-29. First edition. Cham: Springer International Publishing. 973p. doi: https://doi.org/10.1007/978-3-31991944-7_1

Saquet, A. A. (2020). Storage of 'Cox Orange Pippin' Apple Severely Affected by Watercore. Erwerbs-Obstbau. 62: 391-398. doi: https://doi. org/10.1007/s10341-020-00520-y

SAS. (2019). JMP ${ }^{\circledR}$ Version 9.0.2. SAS Institute Inc., Cary, NC, 1989-2019. Recovered from https://support.sas.com/downloads/browse. htm? fil $=$ \&cat $=536$

Slow Food Foundation. (2019). "Gelato Cola" apple. Retrieved from https://www. fondazioneslowfood.com/en/ark-of-taste-slowfood/gelato-cola-apple
Tanaka, F.; Hayakawa, F.; Tatsuki, M. (2020). Flavor and Texture Characteristics of 'Fuji' and Related Apple (Malus domestica L.) Cultivars, Focusing on the Rich Watercore. Molecules. 25(5): 1114. doi: https://doi.org/10.3390/molecules25051114

UPOV- Unión Internacional para la protección de las Obtenciones Vegetales. (2018). Apple (Malus domestica Borkh.). Guidelines for the conduct of tests for distinctness, uniformity and stability. Geneva: UPOV. 45p.

Yamane, T.; Hayama, H.; Mitani, N.; Inoue, H.; Kusaba, S. (2020). Contribution of several fruit quality factors and mineral elements to watersoaked brown flesh disorder in peaches. Scientia Horticulturae. 272: 109523. doi: https://doi. org/10.1016/j.scienta.2020.109523 